\title{
Mineral concentrations in diets, water, and milk and their value in estimating on-farm excretion of manure minerals in lactating dairy cows
}

\author{
A. R. Castillo, ${ }^{* 1}$ N. R. St-Pierre, $†$ N. Silva del Rio, $\ddagger$ and W. P. Weiss $\S$ \\ *University of California, Cooperative Extension, Merced 95341 \\ †Department of Animal Sciences, Ohio Agricultural Research and Development Center, The Ohio State University, Columbus 43210 \\ łUniversity of California, Veterinary Medicine Teaching and Research Center, Tulare 93274 \\ §Department of Animal Sciences, Ohio Agricultural Research and Development Center, The Ohio State University, Wooster 44691
}

\begin{abstract}
Thirty-nine commercial dairies in Merced County, California were enrolled in the present study to (1) compare lactating cow mineral intakes (via drinking water and total mixed ration) to the National Research Council (NRC) requirements, (2) evaluate the association between dietary concentrations of minerals with and without drinking water and adjusted for mineral concentrations in milk, and (3) compare 4 different methods to estimate excretion of minerals using either assays or estimations of milk mineral outputs and total daily mineral intake per cow with or without minerals coming from drinking water. Dairies were selected to represent a range of herd milk yields and a range of water mineral contents. Samples of total mixed ration, drinking water, and bulk tank milk were taken on 2 different days, 3 to $7 \mathrm{~d}$ apart in each farm. Across-farm medians and percentile distributions were used to analyze results. The herd median milk yield interquartile ranged (10th to 90th percentile) from less than 25 to more than $39 \mathrm{~kg} / \mathrm{d}$ and the concentration of total solids in water interquartile ranged from less than 200 to more than $1,490 \mathrm{mg} / \mathrm{L}$. Including drinking water minerals in the diets increased dietary concentrations by $<4 \%$ for all minerals except for $\mathrm{Na}$ and $\mathrm{Cl}$, which increased by 9.3 and $6.5 \%$, respectively. Concentrations of $\mathrm{P}$ and $\mathrm{K}$ in milk were essentially the same as the NRC value to estimate lactation requirements. However, NRC milk values of $\mathrm{Ca}, \mathrm{Cl}$, and $\mathrm{Zn}$ were 10 to $20 \%$ greater than dairy farm values; and $\mathrm{Na}, \mathrm{Cu}, \mathrm{Fe}$, and $\mathrm{Mn}$ were no less than $36 \%$ below NRC values. Estimated excretion of minerals via manure varied substantially across farms. Farms in the 10th percentile did have 2 to 3 times less estimated mineral excretions than those in the 90th percentile (depending on the mineral). Although including water minerals increased excretion of most minerals, the actual median effect of $\mathrm{Ca}, \mathrm{Mg}, \mathrm{S}, \mathrm{Cu}$,
\end{abstract}

Received September 4, 2012.

Accepted January 12, 2013.

${ }^{1}$ Corresponding author: arcastillo@ucanr.edu
Fe, and Mn was less than 5\%, and about $8 \%$ for $\mathrm{Na}$ and $\mathrm{Cl}$. Replacing assayed concentrations of minerals in milk with NRC constants resulted in reduced estimated excretion of $\mathrm{Ca}, \mathrm{Na}, \mathrm{Cu}, \mathrm{Fe}$, and $\mathrm{Zn}$, but median differences were $<5 \%$ except for $\mathrm{Na}$ which was $7.5 \%$. Results indicate that not including mineral intake via drinking water and not using assayed concentrations of milk minerals lead to errors in estimation manure excretion of minerals (e.g., Ca, Na, Cl, and $\mathrm{S}$ ).

Key words: dairy cow, mineral, manure, nutrient management plan

\section{INTRODUCTION}

Dairy cows that consume inadequate amounts of essential nutrients can suffer from a host of health problems and often have reduced milk production and reduced reproductive efficiency (NRC, 2001). Because of numerous uncertainties associated with mineral nutrition, including variation in mineral concentrations of TMR feedstuffs, the lack of information regarding mineral absorption, and potential antagonism with other minerals, diets are often formulated so that mineral intake by cows exceed mineral requirements. Overfeeding minerals can inflate feed costs, reduce absorption of other minerals because of increased antagonism, and have adverse effects on ruminal microbes and the cow (i.e., toxicity; NRC, 2001; 2005). Even if overfeeding minerals has no negative effects on the cow or feed costs, it will certainly result in greater manure excretion of minerals, which could have negative environmental effects.

Accurate estimates of mineral excretion by dairy cows are needed for nutrient management plans (Nennich et al., 2005). In California, the Water Quality Control Board (WQCB) has implemented new water quality regulations based on waste discharge requirements, which affect all California dairy producers. Today, dairy producers in California deal mainly with nitrogen, but also have to calculate $\mathrm{P}$ and $\mathrm{K}$ balances. The WQCB indicates that more minerals will be regulated in the near future. Ten minerals have been identi- 
fied (NRC, 2005) that could be of concern because of their potential negative effects on crop yields or the environment: $\mathrm{Cd}, \mathrm{Cu}, \mathrm{Fe}, \mathrm{Hg}, \mathrm{P}, \mathrm{K}, \mathrm{Na}$, Se, S, and Zn.

Numerous equations have been derived (Morse et al., 1992; Beede and Davidson, 1999; Weiss and Wyatt, 2004; Nennich et al., 2005) to estimate mineral excretion by dairy cows but the underlying function for most equations is as follows: manure excretion of mineral $\mathrm{X}$ = intake of mineral $\mathrm{X}$ - milk secretion of mineral $\mathrm{X}$. In most equations, minerals provided by drinking water are ignored and the concentrations of minerals in milk are assumed constant and book values (e.g., NRC, 2001) are used rather than assayed values. The importance of including information on mineral composition of drinking water and assayed mineral concentrations in milk on estimated mineral balances is not known. The objectives of this project were to (1) compare lactating cow mineral intakes (via drinking water and TMR) to the NRC (2001) requirements, (2) evaluate the association between dietary concentrations of minerals with and without drinking water and adjusted for mineral concentrations in milk, and (3) compare 4 different methods to estimate excretion of minerals using either assays or estimations of milk mineral outputs and total daily mineral intake per cow with or without minerals coming from drinking water.

\section{MATERIALS AND METHODS}

The study was carried out in Merced County, California on 39 commercial dairy farms. The dairy farms were selected to represent a range of herd size (averaging 787 lactating cows, from 210 to 2,435), and a range of milk yield per cow and mineral contents in drinking water. The information was obtained using DHIA records and by personally contacting the dairy owners and dairy operators. Because the herds were not randomly selected, this survey may not necessarily reflect the broader population of dairy farms in California. However, milk yields, herd sizes, and facilities are representative of California dairies. All dairies milked Holstein cows, were using TMR, and had freestalls for lactating animals. None of the dairies declined to participate.

\section{Sampling}

Duplicate samples of TMR, drinking water for animals, and bulk tank milk were obtained on 2 nonconsecutive days (3 to $7 \mathrm{~d}$ apart) from each dairy. Free-choice salts were not included in this survey. Total mixed ration samples from each lactation group were taken by hand immediately after the mixer wagon delivered the feed mix, from the low, middle, and top portion of the feed pile across the entire length of the feed bunk and placed into a $25-\mathrm{L}$ container. The contents of the container were mixed by hand on a clean dry surface and 2 subsamples (about 1-kg each) were placed in sealed plastic bags with minimal air, maintained on ice, and then frozen for later analysis. Wells were the source of drinking water on all dairies in this survey. Water samples were collected into sterile $250-\mathrm{mL}$ bottles from the water line at the entry valve into the water trough. The water ran for about 1 min before the sample was taken, the sample was maintained on ice, and was frozen when it arrived at the laboratory. A composite bulk tank milk sample (a.m. and p.m.) was taken into sterile 250-mL containers, maintained on ice, and then frozen for later analysis.

\section{Chemical Analysis}

Samples of TMR, water, and milk were assayed for $\mathrm{Ca}, \mathrm{P}, \mathrm{Mg}, \mathrm{K}, \mathrm{Na}, \mathrm{Cl}, \mathrm{S}, \mathrm{Cu}, \mathrm{Fe}, \mathrm{Mn}$, Se, and Zn using wet chemistry at the Agriculture and Natural Resources Analytical Laboratory (University of California, Davis). Samples of TMR were oven dried at 55 to $60^{\circ} \mathrm{C}$ for 24 $\mathrm{h}$ and ground to pass through a $400-\mu \mathrm{m}$ screen. Water TS concentration was quantitated using gravimetric analysis following oven drying at 103 to $105^{\circ} \mathrm{C}$ (Clesceri et al., 1998). Samples of TMR, milk, and water TS were digested with nitric acid/hydrogen peroxide via microwave (Sah and Miller, 1992) and concentrations of $\mathrm{Ca}, \mathrm{P}, \mathrm{Mg}, \mathrm{K}, \mathrm{Na}, \mathrm{S}, \mathrm{Cu}, \mathrm{Fe}, \mathrm{Mn}$, and $\mathrm{Zn}$ were determined by inductively coupled plasma atomic emission spectrometry (Meyer and Keliher, 1992). Chloride in the TMR samples was extracted using water and then analyzed by ion chromatography with conductivity detection (Jones, 2001). Chloride in water and milk was quantitated using flow injection analysis based on the formation of ferric thiocyanate with measurement at $480 \mathrm{~nm}$ (Diamond, 1994). Samples of TMR, water TS and milk were digested with a mix of nitric, perchloric, and sulfuric acids, which was followed by reduction with hydrochloric acid. Those digests were assayed for Se by vapor generation inductively coupled plasma emission spectroscopy (Tracy and Moeller, 1990).

\section{Water and DMI}

Dry matter intake was calculated for each lactation group by subtracting the amount of feed refusal from the total amount of TMR delivered per group, multiplying that by the DM concentration of the TMR and then dividing by the number of cows in the group. Farm DMI was calculated by weighting DMI for each pen on the farm by the proportion of total lactating cows in each pen. Water intake for each pen was estimated 
according to Murphy et al. (1983) using pen average milk yield, DMI, preestimated Na intake (TMR and $\mathrm{Na}$ water), and minimum environmental temperature (from the nearest official weather recording station). Farm median water intake for lactating cows was calculated using the same method as farm median DMI.

\section{Milk Yield and Minerals}

Milk production per cow was based on DHIA records (36 farms), and when not available (3 farms), on the total daily bulk tank milk produced divided by the number of lactating cows in each sampling day.

The milk mineral excretions were estimated on the farm average milk yield per cow as follows: (1) multiplying by the assayed concentration of each mineral in the bulk tank milk, or (2) multiplying the average milk yield per cow by concentration of minerals in milk as used by NRC (2001): ( $\mathrm{g} / \mathrm{kg}$ of fluid milk for major minerals) $\mathrm{Ca}, 1.22 ; \mathrm{Cl}, 1.15 ; \mathrm{K}, 1.5 ; \mathrm{Mg}, 0.15 ; \mathrm{Na}$, $1.15 ;(\mathrm{mg} / \mathrm{kg}$ of fluid milk for all trace minerals) P, 0.9; S, 0.4; Cu, 0.15; Fe, 1.0; Mn, 0.03; Se, 0.03; and Zn, 4.0. These average concentrations of minerals in milk are the milk values used by NRC (2001) to estimate absorbed mineral requirements for lactation. Except for $\mathrm{S}$ and Se, where no milk content data are given, a nonfactorial approach based on feed intake was used to estimate requirements (NRC, 2001).

\section{Intake, Requirements, and Estimated Manure Excretion of Minerals}

Farm average DMI, milk yield, and water intake were divided by the number of lactating cows on the farm the day that samples and data were collected. Intakes of minerals (on a per-cow basis) were calculated 2 ways. Dietary intake of each mineral was calculated as measured mineral concentrations of the appropriate TMR times pen average DMI and then a weighted farm average was calculated according to the proportion of animals in each pen. Total intake of each mineral was calculated by summing dietary intake and mineral intake from water. Water mineral intake was calculated by multiplying measured mineral concentrations in water by estimated pen average water intake and then a weighted farm average water mineral intake was calculated according to the proportion of animals in each pen. From the 39 dairies, 33 were feeding a complete mineral mix package in the TMR and did not offer any free-choice minerals. Six dairies offered free-choice $\mathrm{NaCl}, \mathrm{NaHCO}_{3}$, or a mix of the two. Four of those farms fed adequate $\mathrm{NaCl}$ in the TMR, but 2 farms did not include $\mathrm{NaCl}$ in the TMR. Disappearance of free-choice salts was not included in the mineral-intake estimations because immeasurable losses were observed from the feeders and blocks. Excluding free-choice mineral intake will result in an underestimation of $\mathrm{Na}$ and $\mathrm{Cl}$ manure excretion from those 6 farms.

Mineral requirements were calculated using NRC (2001). For S and Se, NRC requirements are set at $0.2 \%$ and $0.4 \mathrm{mg}$ of $\mathrm{S} / \mathrm{kg}$ of diet $\mathrm{DM}$, and the Se requirement is $0.3 \mathrm{mg} / \mathrm{kg}$ of supplemental Se; we assumed dietary ingredients contained $0.1 \mathrm{mg}$ of $\mathrm{Se} / \mathrm{kg}$. For the other minerals, a standard Holstein cow (BW of $650 \mathrm{~kg}$ ) was used for all farms and then average DMI and milk yield for each herd were entered into the model (ambient temperature was set at $20^{\circ} \mathrm{C}$ for all farms) to calculate total absorbed mineral requirements $(\mathrm{g} / \mathrm{d}$ or $\mathrm{mg} / \mathrm{d})$. Those values were divided by typical diet availability coefficients (NRC, 2001): Ca, 0.50; Cl, K, and Na, 0.9; $\mathrm{Mg}, 0.18 ; \mathrm{P}, 0.68 ; \mathrm{Cu}, 0.045 ; \mathrm{Fe}, 0.1 ; \mathrm{Mn}, 0.007$, and $\mathrm{Zn}, 0.15$ (the same values were used for all farms) and then those values were divided by farm average DMI to obtain requirements as a concentration of DMI.

Estimated total daily excretion of minerals in manure was calculated by 4 different methods:

1. Total intake of minerals, from TMR and drinking water, minus assay-measured minerals in the bulk tank milk. All other methods were compared with this method (reference method).

2. Same as 1 (reference method), but not including minerals from drinking water.

3. Same as 1 (reference method), but not including minerals from drinking water and using average NRC (2001) values for milk mineral concentrations.

4. Same as 1 (reference method), but including total intake of minerals, from TMR and drinking water, and using average NRC (2001) values for milk mineral concentrations.

\section{Statistical Analysis}

Across-farm medians and percentile distributions for variables of interest were calculated using PROC UNIVARIATE of SAS (SAS Institute, 2011). Percentiles are shown rather than actual minimum and maximum values because percentiles eliminate extreme outliers and provide more realistic estimates of interquartile ranges in measured variables. Normality was tested using the Shapiro-Wilk test (PROC UNIVARIATE) and data were declared normally distributed at $P>0.05$. Because several variables were not normally distributed, the median is used to express central tendency for all variables. Statistical correlations between dietary (including water) minerals and concentrations of minerals in milk were determined using PROC CORR. The 4 
Table 1. Dairy farm $(\mathrm{n}=39)$ statistics and water composition

\begin{tabular}{|c|c|c|c|c|c|}
\hline Item & Median & \multicolumn{4}{|c|}{ Distribution, percentile } \\
\hline Milk yield, $\mathrm{kg} / \mathrm{d}$ & 32.1 & 24.9 & 27.2 & 35.8 & 39.0 \\
\hline Water intake, ${ }^{1} \mathrm{~kg} / \mathrm{d}$ & 100.6 & 87.1 & 92.4 & 110.5 & 119.3 \\
\hline \multicolumn{6}{|l|}{ Water composition, mg/L } \\
\hline TS & $535^{*}$ & 200 & 335 & 705 & 1,490 \\
\hline $\mathrm{SO}_{4}-\mathrm{S}$ & $11.6^{*}$ & 2.6 & 4.3 & 27.6 & 50.4 \\
\hline $\mathrm{Ca}$ & $65.8^{*}$ & 17.2 & 43.3 & 87.9 & 124.0 \\
\hline $\mathrm{P}$ & $0.10^{*}$ & 0.10 & 0.10 & 0.10 & 0.15 \\
\hline $\mathrm{Mg}$ & $22.2^{*}$ & 3.4 & 8.6 & 39.1 & 60.2 \\
\hline K & $3.0^{*}$ & 1.4 & 2.0 & 4.6 & 7.5 \\
\hline $\mathrm{Na}$ & $60.0^{*}$ & 20.6 & 32.9 & 129.4 & 170.1 \\
\hline $\mathrm{Cl}$ & $49.6^{*}$ & 7.1 & 17.0 & 106.4 & 205.6 \\
\hline
\end{tabular}

${ }^{1}$ Estimated (Murphy et al., 1983).

*Data not normally distributed $(P<0.05)$.

different methods of estimating excretion of minerals were compared using PROC MIXED. The statistical model included the fixed effect of method (the 4 methods to estimate mineral excretion described above) as a repeated measure within farm, and the random effects of farm and the farm by method interaction. An autoregressive covariance structure was used. Three contrasts were used to compare mineral excretion estimated using water and assayed milk values to each of the other methods (i.e., reference method described above).

\section{RESULTS AND DISCUSSION}

The 39 herds were selected to provide a range in water mineral content and milk yields per cow, as is shown in Table 1. The herd median milk yield interquartile ranged from less than 25 to more than $39 \mathrm{~kg} / \mathrm{d}$ and, as expected, DMI was also variable, reflecting the differences in herd median milk yields. The concentration of the TS in drinking water interquartile ranged from less than 200 to more than $1490 \mathrm{mg} / \mathrm{L}$. However, the concentrations of trace minerals $(\mathrm{Cu}, \mathrm{Fe}, \mathrm{Mn}, \mathrm{Se}$, and $\mathrm{Zn}$ ) and $\mathrm{P}$ in the drinking water were not variable across farms (Table 1). Based on the interquartile range between the 10th and 90th percentiles, nitrate-N was the most variable among herds (the 90th percentile was more than 40-fold greater than the 10th percentile). The concentrations of sulfate- $\mathrm{S}, \mathrm{Cl}$, and $\mathrm{Mg}$ in water were also quite variable among herds (the 90th percentile was $>18$-fold greater than the 10 th percentile). The median concentrations of most minerals in this study were similar to median concentrations from a larger survey of water from CA ( $\mathrm{n}=$ approximately 150) and to median concentrations from a survey of livestock water supplies from across the United States $(\mathrm{n}=1,740$ to 4,676, depending on the mineral; Socha et al., 2009). For the US data, median concentrations $(\mathrm{mg} / \mathrm{L})$ for Na, $\mathrm{Cl}$, and $\mathrm{Mn}$ were 14, 24, and 0.03; for the CA subset from that survey, the median concentrations were 64 , 45 , and 0.01 . Those values were generally much lower than the mean concentrations observed in this study (Table 1).

\section{Concentrations of Minerals in Diets}

The dietary concentrations of minerals that would meet NRC (2001) requirements based on reported DMI, actual dietary concentrations, and dietary concentrations including minerals supplied in consumed water are in Tables 2 and 3. When including drinking water minerals, dietary concentrations increased by $<4 \%$ for all minerals except for $\mathrm{Na}$ and $\mathrm{Cl}$ (increased median concentrations by 7 and $5 \%$, respectively). The relative increase caused by water is a function of the concentration of minerals in water (quite low in this study) and the concentration of minerals in the diet.

The macromineral that was fed closest to the requirement was $\mathrm{P}$ (Table 2). The median concentration was about 1.3 times the requirement and about 1.4 times the requirement at the 90 th percentile for dietary $\mathrm{P}$ concentrations. A recent survey indicated that most dairy nutritionists had reduced concentrations of $\mathrm{P}$ in 
Table 2. Approximate NRC (2001) requirements and median concentrations and interquartile ranges of dietary and total (includes those provided by water) macrominerals on 39 California dairy farms ${ }^{1}$

\begin{tabular}{|c|c|c|c|c|c|}
\hline \multirow[b]{2}{*}{ Mineral, $\%$ of diet DM } & \multirow[b]{2}{*}{ Median } & \multicolumn{4}{|c|}{ Distribution, percentile } \\
\hline & & 10th & 25 th & 75th & 90 th \\
\hline \multicolumn{6}{|l|}{ Calcium } \\
\hline Dietary concentration & 0.80 & 0.63 & 0.67 & 0.87 & 0.96 \\
\hline Total concentration ${ }^{2}$ & 0.80 & 0.65 & 0.71 & 0.91 & 1.00 \\
\hline \multicolumn{6}{|l|}{ Phosphorus } \\
\hline \multicolumn{6}{|l|}{ Magnesium } \\
\hline NRC requirement & $0.16^{*}$ & 0.14 & 0.15 & 0.17 & 0.18 \\
\hline Dietary concentration & 0.33 & 0.28 & 0.30 & 0.36 & 0.40 \\
\hline Total concentration & 0.35 & 0.30 & 0.31 & 0.37 & 0.40 \\
\hline \multicolumn{6}{|l|}{ Sodium } \\
\hline NRC requirement & 0.21 & 0.20 & 0.21 & 0.22 & 0.23 \\
\hline Dietary concentration & $0.43^{*}$ & 0.25 & 0.37 & 0.50 & 0.58 \\
\hline \multicolumn{6}{|l|}{ Potassium } \\
\hline NRC requirement & 1.03 & 0.98 & 1.00 & 1.04 & 1.06 \\
\hline Dietary concentration & 1.62 & 1.30 & 1.46 & 1.75 & 1.93 \\
\hline \multicolumn{6}{|l|}{ Sulfur } \\
\hline NRC requirement & 0.20 & 0.20 & 0.20 & 0.20 & 0.20 \\
\hline Dietary concentration & 0.28 & 0.22 & 0.24 & 0.32 & 0.36 \\
\hline Total concentration & 0.29 & 0.22 & 0.25 & 0.32 & 0.36 \\
\hline
\end{tabular}

${ }^{1} \mathrm{NRC}$ (2001) requirements were calculated using pen median milk yield and DMI and breed average BW and typical absorption coefficients.

${ }^{2}$ Total concentrations were calculated by dividing intake of mineral from diet and water by DMI.

*Data not normally distributed $(P<0.05)$.

Table 3. Median concentrations and interquartile ranges of dietary and total (includes those provided by water) trace minerals on 39 California dairy farms and approximate NRC requirements ${ }^{1}$

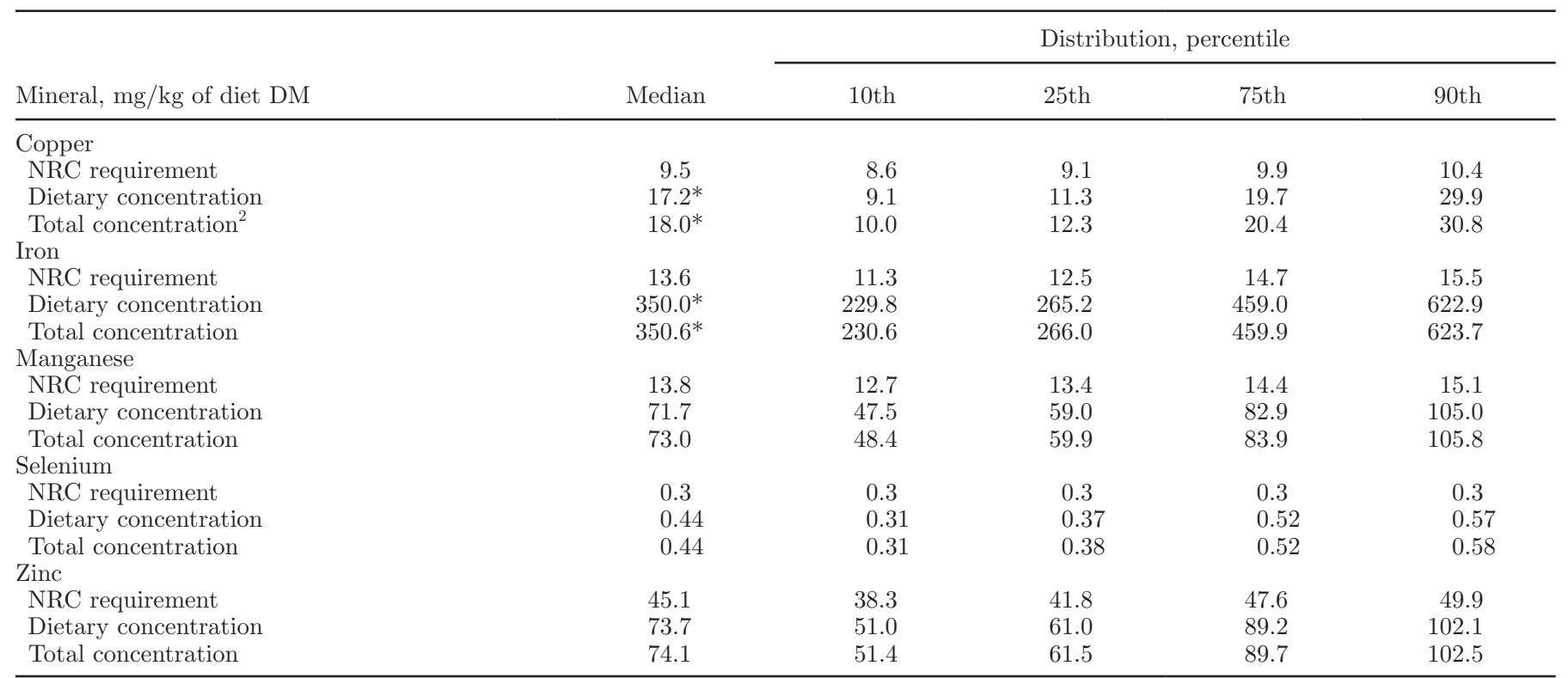

${ }^{1} \mathrm{NRC}$ (2001) requirements were calculated using pen median milk yield and DMI and breed average BW and typical absorption coefficients.

${ }^{2}$ Total concentrations were calculated by dividing intake of mineral from diet and water by DMI.

*Data not normally distributed $(P<0.05)$. 
dairy cow diets (Harrison et al., 2012); however, the degree of median overfeeding of $\mathrm{P}$ (i.e., 1.3 times NRC) was essentially the same as reported in a survey of dairy farms in the northeastern United States conducted in 2002 (Dou et al., 2003). Diets with greater-thanrequired concentrations of $\mathrm{P}$ can cost less than lower-P diets when less expensive byproducts (that often have higher concentrations of $\mathrm{P}$ ) are included in the diet (Stewart et al. 2012). The S median was fed at 1.4 times the requirement (1.8 times the requirement at the 90th percentile). Diets with as little as $0.4 \%$ S (i.e., 2 times the requirement) can have detrimental effects to cattle, ranging from secondary $\mathrm{Cu}$ and Se deficiencies to polioencephalomalacia (NRC, 2005), which may be the reason that dietary $\mathrm{S}$ concentrations are relatively close to requirements. Median Ca and K concentrations were about 1.4 and 1.6 times the requirement, respectively, and about 1.5 for both minerals when compared with the 10th to 90 th percentiles (Table 2) but some of this overfeeding is likely caused by concentrations of those minerals in the TMR ingredients. Median concentrations of $\mathrm{Mg}, \mathrm{Na}$, and $\mathrm{Cl}$ were more than 2 times the requirement and 10th to 90th percentile differences were 1.3. 2.0, and 1.9, respectively. Dietary K interferes with $\mathrm{Mg}$ absorption (Fisher et al., 1994; Weiss, 2004; Schonewille et al., 2008). However, the NRC requirement does not consider antagonisms among minerals when establishing requirements. In addition, dietary $\mathrm{Mg}$ (provided by $\mathrm{MgO}$ ) concentrations greater than NRC requirements can increase milk fat concentrations and yields (Erdman, 1988). Therefore, some overfeeding of $\mathrm{Mg}$ can be justified; however in this study, dietary concentrations of $\mathrm{K}$ and $\mathrm{Mg}$ were not correlated $(P>0.15)$, suggesting that dietary $\mathrm{K}$ was not a major factor influencing $\mathrm{Mg}$ supplementation. Sodium and $\mathrm{Cl}$ were also substantially overfed by all herds and as expected concentrations were correlated indicating an oversupplementation of $\mathrm{NaCl}$. Excess (i.e., greater than NRC) Na from sodium bicarbonate or other Na-based buffers can increase milk fat concentration and yield (Erdman, 1988).

For trace minerals (Table 3 ), dietary concentrations were approximately $1.1(\mathrm{Se})$ to $26(\mathrm{Fe})$ times greater than requirements. The Se requirement is $0.3 \mathrm{mg} / \mathrm{kg}$ of supplemental Se and we assumed that dietary ingredients contained $0.1 \mathrm{mg}$ of $\mathrm{Se} / \mathrm{kg}$. Dietary Fe far exceeded the requirement but this was likely caused by TMR ingredients. Many feeds, especially forages, have extremely high concentrations of Fe but because of the low bioavailability of that $\mathrm{Fe}$, it is not an animal toxicity issue (NRC, 2005). The median Mn concentration was about 5 times greater than the NRC (2001) requirement; however, more recent publications (Weiss and Socha, 2005; Hansen et al., 2006) indicate that the NRC Mn requirement is too low, which justifies greater than NRC dietary concentrations. The median $\mathrm{Cu}$ concentration was about 1.9 times greater than the requirement but at the 90th percentile, $\mathrm{Cu}$ concentration was 3 times greater than the requirement. Sulfur, Mo, and Fe can interfere with $\mathrm{Cu}$ absorption or increase the $\mathrm{Cu}$ requirement, which can be used to justify oversupplementation of $\mathrm{Cu}$, but no correlations $(P>0.15)$ were found between dietary $\mathrm{Cu}$ concentrations and dietary or total concentrations of $\mathrm{S}$ or Fe. Diets with up to $20 \mathrm{mg}$ of supplemental $\mathrm{Cu} / \mathrm{kg}$ reduce the severity of mastitis compared with diets containing $<10 \mathrm{mg}$ of total $\mathrm{Cu} / \mathrm{kg}$ (Scaletti et al., 2003), which is additional justification for modest overfeeding of $\mathrm{Cu}$. Median $\mathrm{Zn}$ was overfed at approximately the same rate as was $\mathrm{Cu}$ (1.6 times) but at the 90th percentile, $\mathrm{Zn}$ was overfed at only 2 times the requirement compared with 3 times the requirement for $\mathrm{Cu}$. Improvements in mammary gland health and increased milk yield have been reported when cows were fed diets with about 62 $\mathrm{mg}$ of total $\mathrm{Zn} / \mathrm{kg}$ (approximately 1.4 times the NRC requirement) compared with those fed approximately NRC requirements (Cope et al., 2009). These potential benefits support modest overfeeding of $\mathrm{Zn}$.

Maximum tolerable levels (MTL) are defined as "the dietary level that, when fed for a defined period of time, will not impair animal health and performance" (NRC, 2005). Median concentrations (i.e., diet plus water minerals) of all measured minerals were below the established MTL. At the 90th percentile, for total concentrations most minerals were at least $30 \%$ less than the MTL, except for K and Fe. The K concentration was approximately at the MTL (90th percentile = 1.93 vs. MTL of $2 \%$ ) and concentrations of Fe exceeded the MTL (90th percentile $=624$ vs. MTL of $500 \mathrm{mg} /$ $\mathrm{kg}$ ). The MTL for Fe is based on readily available Fe but forages were likely the source of most Fe in these diets, which has very poor bioavailability (Hansen and Spears, 2009); therefore, even the highest Fe concentrations fed in this study are likely not a problem. The mostly likely problem associated with $\mathrm{K}$ concentration of approximately $2 \%$ for lactating cows is reduced $\mathrm{Mg}$ absorption, but because all herds fed excess Mg, problems with high $\mathrm{K}$ were unlikely.

\section{Concentrations of Minerals in Milk}

The median values for minerals in milk in this study are similar to other recent surveys (Robinson et al., 2002; Gaucheron, 2005; van Hulzen et al., 2009). The median concentrations of $\mathrm{P}$ and $\mathrm{K}$ in milk were similar to the NRC (2001) values to estimate lactation requirements for those minerals (Table 4). Even at the extremes (10th or 90th percentiles), concentrations 
Table 4. Median and interquartile ranges of concentrations $(\mathrm{mg} / \mathrm{kg})$ of minerals in milk on 39 California dairy farms

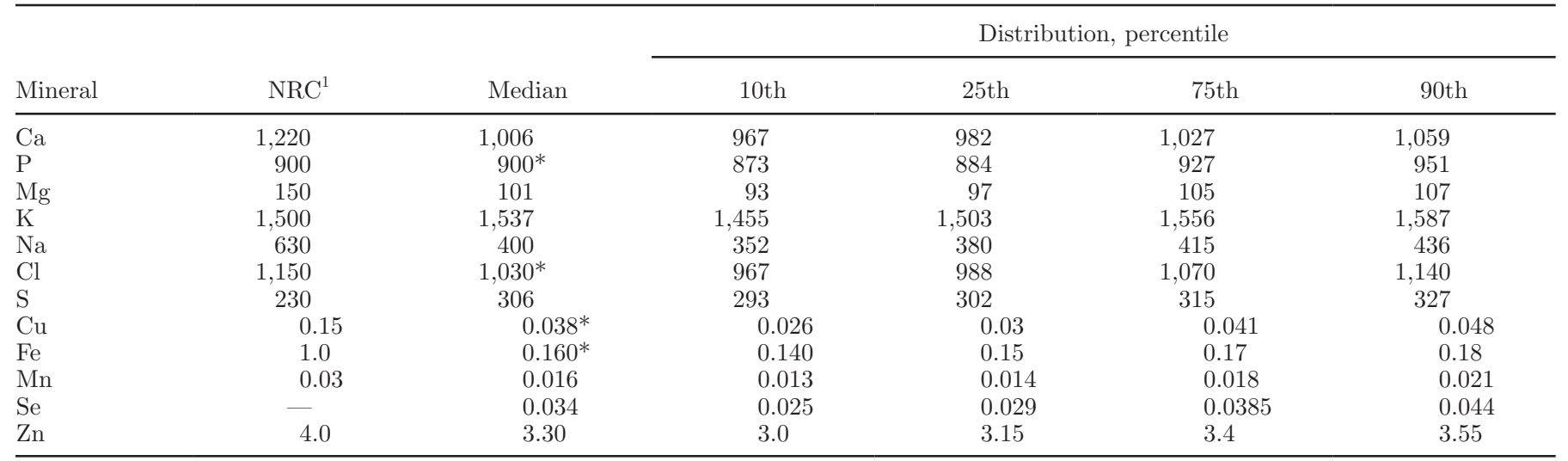

${ }^{1}$ Concentration of mineral in milk used to calculate the lactation requirement (NRC, 2001). The NRC does not use milk content to calculate lactation requirement for $\mathrm{S}$ and Se. The $\mathrm{S}$ concentration in milk is from NRC (2003).

*Data not normally distributed $(P<0.05)$.

were within $3 \%$ of the NRC value. The NRC values for $\mathrm{Ca}, \mathrm{Cl}$, and $\mathrm{Zn}$ were 10 to $20 \%$ greater than the median values and the median concentrations of $\mathrm{Na}$, $\mathrm{Cu}, \mathrm{Fe}$, and $\mathrm{Mn}$ are much (more than $36 \%$ ) less than the NRC values. The value from NRC (2003) for S (NRC, 2001) was about 25\% lower than the median bulk tank milk assayed concentration and was lower than the 10th percentile value. Among herds, the variation in milk mineral concentration was low and dietary minerals (with and without including water) concentrations were not correlated $(P>0.15)$ with the mineral concentrations in milk (data not shown). For $\mathrm{Cu}, \mathrm{Fe}$, and Mn, the NRC (2001) values for milk concentrations were approximately 2 to 6 times greater than the measured mean concentrations; however, because these concentrations in bulk tank milk are so low these large errors had little overall effect on estimated requirements. Using the NRC (2001) value for Fe, the median cow in this study ( $32 \mathrm{~kg}$ of milk) would secrete $32 \mathrm{mg}$ of Fe in the milk daily, but using the median Fe bulk tank milk concentration from this study, that cow would secrete only $5 \mathrm{mg} / \mathrm{d}$. For animal excretion estimations (milk and manure), the calculated Fe difference (27 $\mathrm{mg}$ ) needs to be compared with the median intake of Fe in this study $(8,955 \mathrm{mg} / \mathrm{d})$ and the median intake of available (as estimated by NRC) Fe $(896 \mathrm{mg} / \mathrm{d}$ ). For macrominerals, the greatest difference between the NRC value and the mean concentration in milk was for Na. The NRC (2001) value was $233 \mathrm{mg} / \mathrm{L}$ greater than the mean bulk tank milk value. The median cow in this study secreted $7.5 \mathrm{~g} / \mathrm{d}$ less $\mathrm{Na}$ in milk than the NRC (2001) estimates. Compared with a daily intake of $100 \mathrm{~g}$ of $\mathrm{Na}$, the difference is not trivial, suggesting that either the value used by NRC (2001) to estimate the lactation requirement for $\mathrm{Na}$ should be reevaluated or actual milk concentrations of $\mathrm{Na}$ should be used to determine requirements.

\section{Estimating Excretion of Minerals}

The reference method for estimating mineral excretion for this project was to calculate total intake of each mineral (diet and water) and subtracting the amount of mineral secreted in milk based on assayed milk minerals (Table 5). Because of waste and weather-caused washout, among other factors, disappearance of free-choice minerals is likely greater than intake of free-choice minerals. Therefore, we chose not to include disappearance of free-choice minerals to estimate manure excretion of minerals. However, for whole-farm nutrient management programs, it must be included because the mineral that is lost will eventually enter the waste stream. Not including free-choice mineral intake means that we would underestimate the excretion of sodium and chloride on 6 of the 39 farms in this survey. Consumption of free-choice salt by lactating dairy cows is affected by the type of salt and the salt concentration of the diet. Dairy cows fed a diet with $0.1 \% \mathrm{Na}$ consumed $34 \mathrm{~g}$ of $\mathrm{NaCl} / \mathrm{d}$ from blocks compared with $24 \mathrm{~g} / \mathrm{d}$ for cows fed a diet with $0.17 \% \mathrm{Na}$ (Valk and Kogut, 1998). Those dietary concentrations are lower concentrations than observed in the current survey, suggesting that free-choice $\mathrm{NaCl}$ intake would be less than $24 \mathrm{~g} / \mathrm{d}$ (approximately 9 and $13 \mathrm{~g} / \mathrm{d}$ of $\mathrm{Na}$ and $\mathrm{Cl}$, respectively) measured by Valk and Kogut (1998). This is approximately $10 \%$ of the median estimated excretion of those 2 minerals. Because free-choice $\mathrm{NaCl}$ or $\mathrm{NaHCO}_{3}$ was fed on only 6 farms ( $15 \%$ of the farms), not including disappearance of free-choice $\mathrm{Na}$ and $\mathrm{Cl}$ would not greatly affect the median excretion for those minerals observed in the 
Table 5. Medians and distributions of estimated lactating dairy cow mineral excretion in manure on 39 California dairy farms ${ }^{1}$

\begin{tabular}{|c|c|c|c|c|c|}
\hline Mineral & Median & \multicolumn{4}{|c|}{ Distribution, percentile } \\
\hline \multicolumn{6}{|c|}{ Major mineral, $\mathrm{g} / \mathrm{d}$} \\
\hline Phosphorus & 74.5 & 52.0 & 60.8 & 89.1 & 99.2 \\
\hline Magnesium & 77.1 & 61.7 & 70.9 & 85.0 & 94.3 \\
\hline Potassium & 321.2 & 239.5 & 273.0 & 370.1 & 424.6 \\
\hline Sulfur & 59.7 & 38.2 & 46.6 & 69.0 & 73.3 \\
\hline \multicolumn{6}{|c|}{ Trace mineral, mg/d } \\
\hline Copper & $417^{*}$ & 232 & 263 & 471 & 725 \\
\hline Iron & $8,255^{*}$ & 5,035 & 6,168 & 10,569 & 14,572 \\
\hline Manganese & 1,784 & 1,133 & 1,368 & 2,127 & 2,420 \\
\hline Selenium & 9.1 & 6.5 & 7.3 & 11.7 & 12.3 \\
\hline Zinc & 1,693 & 919 & 1,336 & 1,982 & 2,291 \\
\hline
\end{tabular}

${ }^{1}$ Mineral excretion was estimated by summing total mineral intake (TMR + drinking water) and subtracting minerals secreted in cow's milk calculated from milk yield per cow and assayed concentrations of minerals in bulk tank milk.

*Data not normally distributed $(P<0.05)$.

current study, but on a specific farm, the error could be important and disappearance of free-choice minerals should be included when estimating excretion.

Estimated excretion of minerals varied substantially across farms. Comparing the 10th to the 90th percentile, excretion of most minerals varied by a factor of 2 to 3. Compared with among-farm variation, the method of estimating excretion had a minor effect (Table 6). Not including mineral consumption via water reduced $(P$ $<0.05)$ the estimated manure excretion of all minerals except $\mathrm{P}, \mathrm{K}$, and Se because water contained very low concentrations of the minerals (Table 4; Figure 1). For $\mathrm{Ca}, \mathrm{Mg}, \mathrm{S}, \mathrm{Cu}, \mathrm{Fe}$, and $\mathrm{Mn}$, including water minerals increased the estimated excretion by less than $5 \%$. For $\mathrm{Na}$ and $\mathrm{Cl}$, the difference was about $8 \%$. The effect of not including water minerals on estimated mineral excretion on farms in this study was small; however, the degree of error associated with not including water minerals in calculations is dependent on water composition and can vary greatly between farms.

Table 6. Effect of method of estimating manure excretion of minerals

\begin{tabular}{|c|c|c|c|c|}
\hline \multirow{2}{*}{ Mineral } & \multicolumn{4}{|c|}{ Method $^{1}$} \\
\hline & $\begin{array}{l}\text { Reference } \\
\text { method }\end{array}$ & \multicolumn{2}{|c|}{ Not including water minerals } & $\frac{\text { With water minerals }}{\text { Tot }+ \text { NRC }}$ \\
\hline \multicolumn{5}{|c|}{ Macromineral, g/d } \\
\hline Calcium & 156.6 & $149.8^{* *}$ & $143.0^{* *}$ & $149.9^{* *}$ \\
\hline Phosphorus & 74.5 & 74.5 & 74.7 & 74.5 \\
\hline Sodium & 97.4 & $88.7^{* *}$ & $81.2^{* *}$ & $90.0^{* *}$ \\
\hline Chloride & 118.4 & $109.6^{*}$ & $106.0^{*}$ & 114.8 \\
\hline Sulfur ${ }^{2}$ & 57.7 & $55.6^{* *}$ & 58.1 & $60.2^{*}$ \\
\hline \multicolumn{5}{|c|}{ Trace mineral, mg/d } \\
\hline Copper & 420 & $400^{* *}$ & $396^{* *}$ & $416^{* *}$ \\
\hline Iron & 8,917 & $8,897^{* *}$ & $8,871^{* *}$ & $8,891^{* *}$ \\
\hline Manganese & 1,727 & $1,704^{* *}$ & $1,703^{* *}$ & 1,726 \\
\hline
\end{tabular}

${ }^{1}$ Methods to estimate mineral excretion were as follows: (1) reference method: total intake of minerals (TMR + drinking water) minus assaymeasured minerals in the bulk tank milk (all other methods were compared with the reference method); (2) same as reference method, but not including minerals from drinking water (diet + assay); (3) same as reference method, but not including minerals from drinking water and using median NRC (2001) values for milk mineral concentrations (diet + NRC); and (4) same as reference method, including all minerals (TMR + drinking water) and using average NRC (2001) values for milk mineral concentrations (Tot + NRC).

${ }^{2}$ NRC (2001) does not provide average concentration for S and Se in milk. Data from NRC (2003) was used to estimate S concentration in milk. *Differ from: 1. reference method $(P<0.05)$ or ** $(P<0.01)$. 
a)
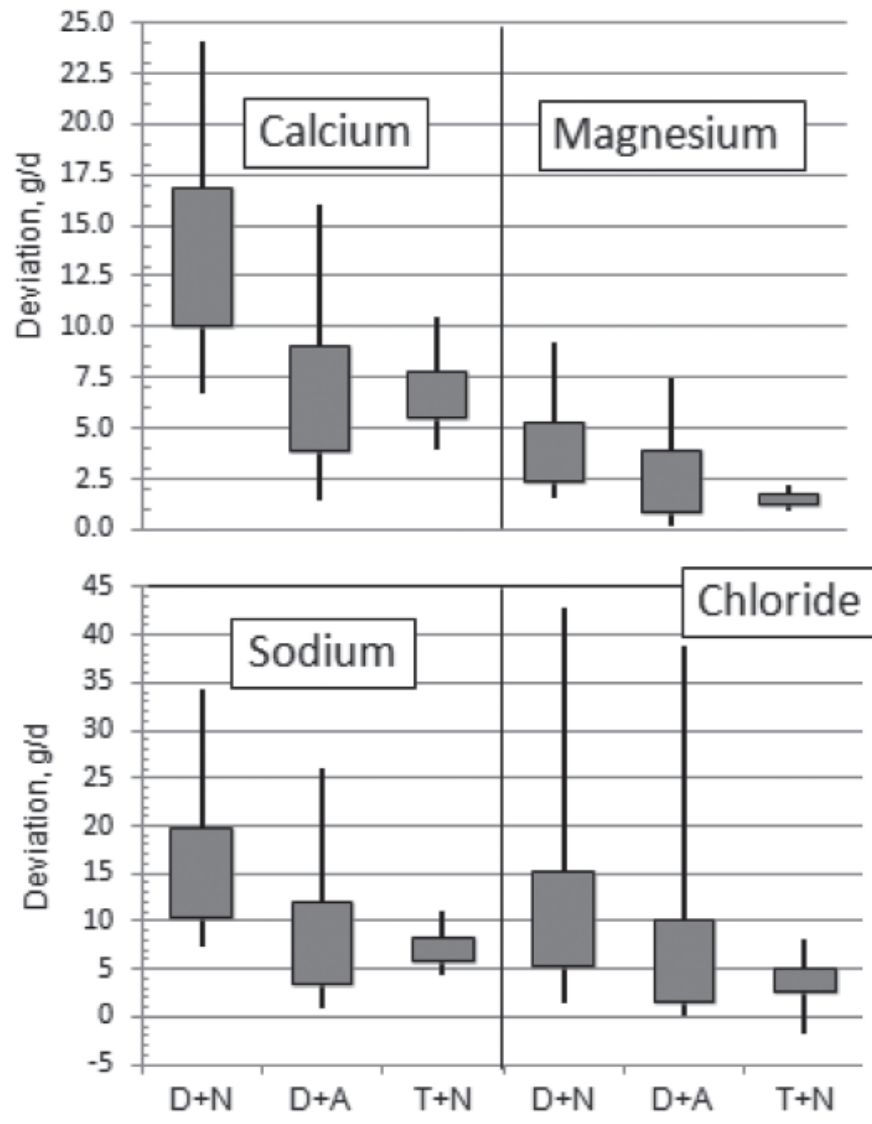

b)

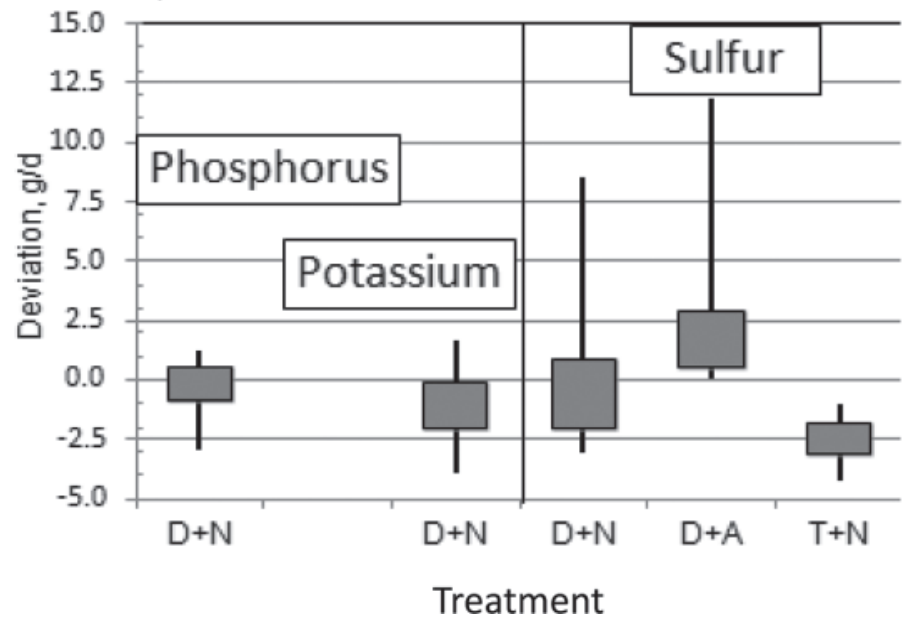

c)
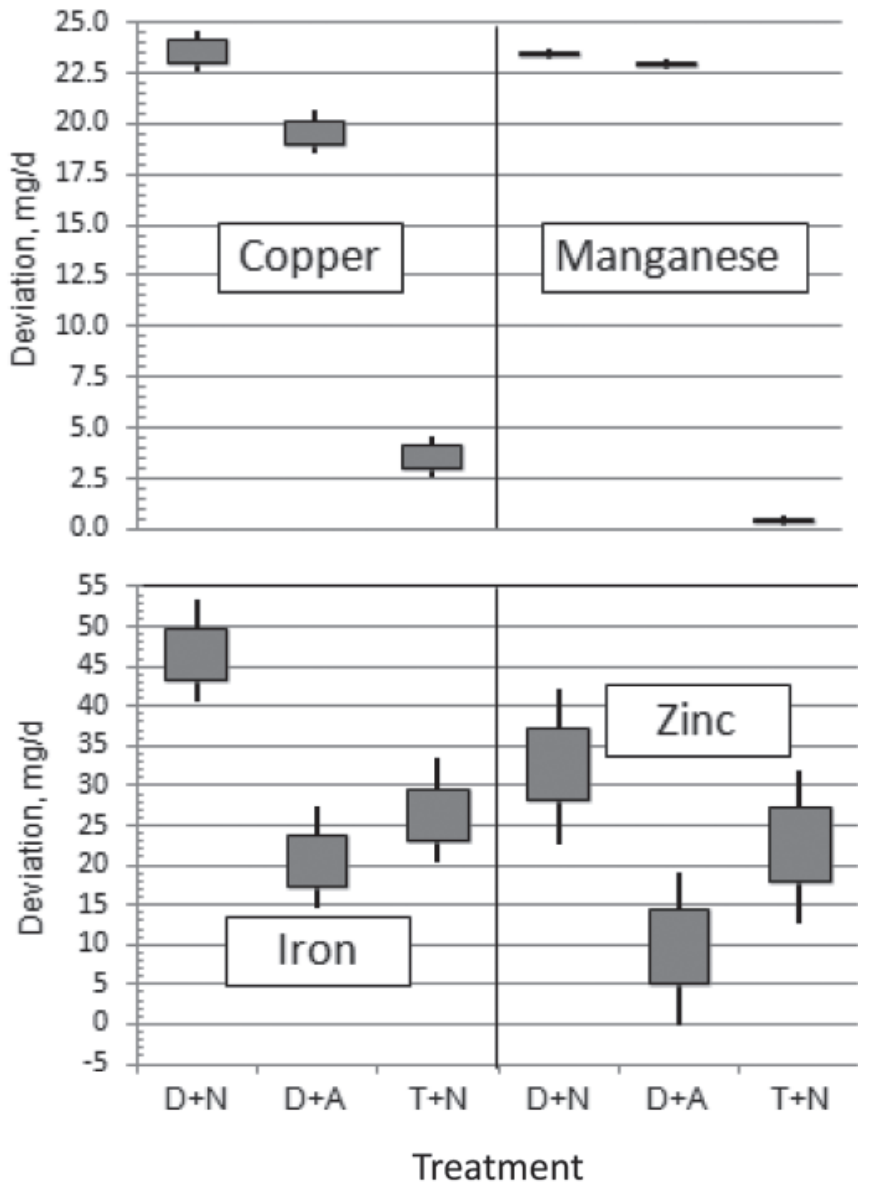

Figure 1. Comparison of different methods to estimate manure excretion of $\mathrm{Ca}, \mathrm{Mg}, \mathrm{Na}$, and $\mathrm{Cl}(\mathrm{a})$; $\mathrm{P}, \mathrm{K}$, and $\mathrm{S}$ (b); and $\mathrm{Cu}, \mathrm{Mn}, \mathrm{Fe}$, and $\mathrm{Zn}$ (c). The y axis represents the deviation $(\mathrm{g} / \mathrm{d}$ or $\mathrm{mg} / \mathrm{d}$ ) from the reference method, calculated as follows: intake of mineral from diet and water - secretion of mineral in milk (i.e., milk yield $\times$ assayed concentration of mineral). Mineral excretion was also estimated using that equation except (1) water minerals were not included and NRC milk concentrations were used $(\mathrm{D}+\mathrm{N})$; (2) water minerals were not included but milk minerals were assayed (D+A); and (3) all minerals (TMR + drinking water) and concentrations of minerals in milk from NRC (2001) were used rather than assayed concentrations $(\mathrm{T}+\mathrm{N})$. Boxes indicate the 25 th to 75 th percentile limits and lines indicate the 5 th and 95 th percentile limits. 
Replacing assayed concentrations of minerals in milk with NRC (2001) constants resulted in reduced $(P<$ 0.01 ) estimates of excretion of $\mathrm{Ca}, \mathrm{Na}, \mathrm{Cu}, \mathrm{Fe}$, and $\mathrm{Zn}$ (Table 4 ), but the median actual differences were $<5 \%$ except for $\mathrm{Na}$, which was $7.5 \%$. When NRC constants were used and minerals supplied by water were ignored, the estimated excretion was different for $\mathrm{Ca}, \mathrm{Mg}, \mathrm{Na}$, $\mathrm{Cu}, \mathrm{Fe}, \mathrm{Mn}, \mathrm{Zn}($ all $P<0.01)$, and $\mathrm{S}$ and $\mathrm{Cl}(P<0.05)$. The actual differences between estimated excretion using water and assayed minerals and not using water with NRC constants for the trace minerals were less than $2 \%$, except for $\mathrm{Cu}$, which was $5.7 \%$. Median differences for the major mineral interquartile ranged from $5.4 \% \mathrm{Mg}$ to $17 \%$ for $\mathrm{Na}$ (P and $\mathrm{K}$ did not differ between methods of estimation). Because nutrient management programs are for individual farms, not average farm, across farm interquartile ranges, the differences between the reference method and other estimation methods are important. Interquartile ranges for $50 \%$ (25th to 75 th percentiles) and $90 \%$ (5th to 95th percentiles) for major and trace minerals are in Figures 1a, b, and c. For $\mathrm{P}$ and $\mathrm{K}$ (Figure 1b), even at the extreme (95th percentile), the estimation methods introduced only minor errors on a daily basis. However, errors will accumulate over days so that the $4 \mathrm{~g} / \mathrm{d}$ per cow overestimation of K excretion when NRC (2001) milk concentration value is used converts to a $1.2 \mathrm{~kg} /$ cow overestimation for a 305-d lactation. For some major minerals (Ca, Na, Cl, and S), substantial errors (Figures 1a and b) occurred for some farms, justifying including water minerals and assayed milk minerals when calculating on farm mineral balances. The potential farm-to-farm variation justifies including water minerals in estimated excretion calculations because water sampling and analysis is straightforward and easily accomplished in the field. The importance of including water and assayed milk concentrations when calculating trace mineral balances is less clear (Figure 1c). For example, using the most extreme farms in this data set, estimated excretions of $\mathrm{Cu}, \mathrm{Fe}$, and $\mathrm{Zn}$ were underestimated compared with the reference method by about 8, 16, and $12 \mathrm{~g} / 305-\mathrm{d}$ lactation per cow. For farms with a large number of animals and limited land base for manure applications, these errors could be important.

Accurate estimates of mineral excretion on dairy farms are needed in some regions for development of nutrient-management plans. Mass balance can be an accurate method to estimate excretion and is calculated from easily measurable or obtainable inputs. Minerals enter an animal via water and diet and are either secreted in milk, excreted in manure, or retained in their bodies or in the growing fetus. For this study, mineral excretion was estimated only for lactating cows, and mineral accretion in the fetus was trivial during most of the lactation period and could be ignored. Body retention of minerals is a function of growth (mostly macrominerals) and tissue accumulation is caused by excessive intake of minerals (mostly trace minerals). Total removal of $\mathrm{K}, \mathrm{Mg}, \mathrm{P}, \mathrm{S}, \mathrm{Cu}$, and $\mathrm{Zn}$ from dairy farms via animals (this would include cows and calves that were sold) was estimated by Hristov et al. (2006, 2007). On a daily per-lactating cow basis, this accounted for approximately $5 \mathrm{~g} / \mathrm{d}$ for P, $2 \mathrm{~g} / \mathrm{d}$ for $\mathrm{K}, 1 \mathrm{~g} / \mathrm{d}$ for $\mathrm{S}, 0.3 \mathrm{~g} / \mathrm{d}$ for $\mathrm{Mg}, 15 \mathrm{mg} / \mathrm{d}$ for $\mathrm{Zn}$, and $<1 \mathrm{mg} / \mathrm{d}$ for $\mathrm{Cu}$. Much of this accumulation of minerals would occur during the heifer-rearing stage and not during the lactation period and, relative to daily intakes of these minerals, the amounts are minor (e.g., $4.9 \%$ for P, $0.3 \%$ for $\mathrm{K}, 0.4 \%$ for $\mathrm{Mg}, 1.1 \%$ for $\mathrm{S}, 0.2 \%$ for $\mathrm{Cu}$, and $0.7 \%$ for Zn; Hristov et al., 2006, 2007).

\section{CONCLUSIONS}

The main objective of this project was to determine the effect of including water minerals and using assayed milk composition to estimate the excretion of minerals. For some farms in this study, ignoring minerals consumed via water and using NRC constants for estimating milk secretion of minerals rather than assayed concentrations introduced significant errors when estimating manure excretion of minerals via the mass balance technique. Mineral excretion data from our study are not necessarily extrapolatable to other farms; however, the ability to identify farms a priori that should include measured mineral data for water and milk is not possible at this time. Therefore, sampling and analyzing water and milk for mineral concentrations should be considered for all farms that are estimating mineral excretion via mass balance. Although not measured in this experiment, ignoring disappearance of free-choice minerals in the mass balance equation is another potential error and should be included when calculating whole-farm mineral balances or when developing nutrient management plans.

\section{ACKNOWLEDGMENTS}

This project was financed by the University of California, Agriculture and Natural Resources, ANR Core Issues Grants Program. The authors thank dairy producers in Merced County, California for their support and participation in this study, and the permanent help of the staff at the University of California Cooperative Extension, Merced County office.

\section{REFERENCES}

Beede, D. K., and J. A. Davidson. 1999. Phosphorus: Nutritional management for Y2K and beyond. Pages 51-97 in Proc. Tri-State 
Dairy Nutr. Conf., Ft. Wayne, IN. M. L. Eastridge, ed. The Ohio State University, Columbus.

Clesceri, L. S., A. E. Greenberg, and A. D. Eaton, editors. 1998. Method 2540 B. Pages 2-55-59 in Standard Methods for the Examination of Water and Wastewater. 20th ed. American Public Health Association, Washington, DC.

Cope, C. M., A. M. Mackenzie, D. Wilde, and L. A. Sinclair. 2009. Effects of level and form of dietary zinc on dairy cow performance and health. J. Dairy Sci. 92:2128-2135.

Diamond, D. 1994. Determination of chloride by flow injection analysis colorimetry. QuikChem method 10-117-07-1-B. Lachat Instruments, Milwaukee, WI.

Dou, Z., J. D. Ferguson, J. Fiorini, J. D. Toth, S. M. Alexander, L. E. Chase, C. M. Ryan, K. F. Knowlton, R. A. Kohn, A. B. Peterson, J. T. Sims, and Z. Wu. 2003. Phosphorus feeding levels and critical control points on dairy farms. J. Dairy Sci. 86:3787-3795.

Erdman, R. A. 1988. Dietary buffering requirements of the lactating dairy cow: A review. J. Dairy Sci. 71:3246-3266.

Fisher, L. J., N. Dinn, R. M. Tait, and J. A. Shelford. 1994. Effect of level of dietary potassium on the absorption and excretion of calcium and magnesium by lactating cows. Can. J. Anim. Sci. 74:503-509.

Gaucheron, F. 2005. The minerals of milk. Reprod. Nutr. Dev. 45:473-483.

Hansen, S. L., and J. W. Spears. 2009. Bioaccessibility of iron from soil is increased by silage fermentation. J. Dairy Sci. 92:2896-2905.

Hansen, S. L., J. W. Spears, K. E. Lloyd, and C. S. Whisnant. 2006. Feeding a low manganese diet to heifers during gestation impairs fetal growth and development. J. Dairy Sci. 89:4305-4311.

Harrison, J. H., K. F. Knowlton, B. James, M. D. Hanigan, C. Stallings, and E. Whitefield. 2012. Case study: National survey of barriers related to precision phosphorus feeding. Prof. Anim. Sci. $28: 564-568$.

Hristov, A. N., J. W. Ellsworth, and W. Hazen. 2006. Efficiency of use of imported nitrogen, phosphorus, and potassium and potential for reducing phosphorus imports on Idaho dairy farms. J. Dairy Sci. 89:3702-3712

Hristov, A. N., W. Hazen, and J. W. Ellsworth. 2007. Efficiency of use of imported magnesium, sulfur, copper, and zinc on Idaho dairy farms. J. Dairy Sci. 90:3034-3043.

Jones, J. B. 2001. Laboratory Guide for Conducting Soil Tests and Plant Analysis. Pages 227-228. 1st ed. CRC Press, Boca Raton, FL.

Meyer, G. A., and P. N. Keliher. 1992. An overview of analysis by inductively coupled plasma-atomic emission spectrometry. Pages 473-516 in Inductively Coupled Plasmas in Analytical Atomic Spectrometry. A. Montaser and D. W. Golightly, ed. VCH Publishers Inc. New York, NY.

Morse, D., H. H. Head, C. J. Wilcox, H. H. Van Horn, C. D. Hissem, and B. Harris Jr. 1992. Effects of concentration of dietary phosphorous on amount and route of excretion. J. Dairy Sci. 75:3039-3049.

Murphy, M. R., C. L. Davis, and G. C. McCoy. 1983. Factors affecting water consumption by Holstein cows in early lactation. J. Dairy Sci. $66: 35-38$
NRC. 2001. Nutrient Requirements of Dairy Cattle. 7th rev. ed. Natl Acad. Press, Washington, DC.

NRC. 2003. Air Emissions from Animal Feeding Operations: Current Knowledge, Future Needs. Page 208. Natl. Acad. Press, Washington, DC.

NRC. 2005. Mineral Tolerance of Animals. 2nd rev. ed. Natl. Acad Press, Washington, DC.

Nennich, T. D., J. H. Harrison, L. M. VanWieringen, D. Meyer, A J. Heinrichs, W. P. Weiss, N. R. St-Pierre, R. L. Kincaid, D. L. Davidson, and E. Block. 2005. Prediction of manure and nutrient excretion from dairy cattle. J. Dairy Sci. 88:3721-3733.

Robinson, P. H., T. Beaucaire, and D. Meyer. 2002. Mineral levels in bulk milk of California dairy cows. Pages 1-6. Univ. CA Coop. Ext. Accessed July 11, 2012. http://animalscience.ucdavis.edu/ faculty/robinson/Articles/FullText/PDF/Web200211.pdf.

Sah, R. N., and R. O. Miller. 1992. Spontaneous reaction for acid dissolution of biological tissues in closed vessels. Anal. Chem. 64:230-233.

SAS Institute. 2011. SAS/STAT ${ }^{\circledR} 9.3$ User's Guide. SAS Inst. Inc. Cary, NC.

Scaletti, R. W., D. S. Trammell, B. A. Smith, and R. J. Harmon. 2003. Role of dietary copper in enhancing resistance to Escherichia coli mastitis. J. Dairy Sci. 86:1240-1249.

Schonewille, J. T., H. Everts, S. Jittakhot, and A. C. Beynen. 2008. Quantitative prediction of magnesium absorption in dairy cows. J. Dairy Sci. 91:271-278.

Socha, M. T., D. J. Tomlinson, and J. M. DeFrain. 2009. Variability of water composition and potential impact on animal performance. Pages 58-70 in Proc. Calif. Anim. Nutr. Conf., Fresno, CA. CANC 2009 Steering Committee, ed.

Stewart, B. A., R. E. James, M. D. Hanigan, and K. F. Knowlton. 2012. Cost of reducing protein and phosphorus content in dairy rations. Prof. Anim. Sci. 28:115-119.

Tracy, M. L., and G. Moeller. 1990. Continuous flow vapor generation for inductively coupled argon plasma spectrometric analysis. Part 1: Selenium. J. Assoc. Off. Anal. Chem. 73:404-410.

Valk, H., and J. Kogut. 1998. Salt block consumption by high yielding dairy cows fed rations with different amounts of $\mathrm{NaCl}$. Livest. Prod. Sci. 56:35-42.

van Hulzen, K. J. E., R. C. Sprong, R. van der Meer, and J. A. M. van Arendonk. 2009. Genetic and nongenetic variation in concentration of selenium, calcium, potassium, zinc, magnesium, and phosphorus in milk of Dutch Holstein-Friesian cows. J. Dairy Sci. 92:5754-5759.

Weiss, W. P. 2004. Macromineral digestion by lactating dairy cows: Factors affecting digestibility of magnesium. J. Dairy Sci $87: 2167-2171$

Weiss, W. P., and M. T. Socha. 2005. Dietary manganese for dry and lactating Holstein cows. J. Dairy Sci. 88:2517-2523.

Weiss, W. P., and D. J. Wyatt. 2004. Macromineral digestion by lactating dairy cows: Estimating phosphorus excretion via manure. J. Dairy Sci. 87:2158-2166. 